\title{
Research on the Teaching Reform of Logistics - Flipped Classroom Under the OBE Concept
}

\author{
Jing Song* \\ Department of Port and Shipping Management, Guangzhou Maritime University, Guangzhou 510725, China \\ *Corresponding author: Jing Song, 84864809@qq.com
}

\begin{abstract}
This article discusses the problems existing in the teaching of Logistics and the urgency of its curriculum reform, introduces the concept of outcome-based education (OBE) into the teaching process of Logistics, designs the teaching in a reverse direction guided by the results, and implements the teaching design in the form of flipped classroom. A "studentcentered" teaching process endows students with stronger autonomy and initiative and encourages them to cooperate with each other. This teaching process provides new ideas and methods for the teaching reform of Logistics as well as the cultivation of excellent logistics talents.
\end{abstract}

Keywords: OBE; Flipped classroom; Result-oriented; Logistics

Publication date: November 2021; Online publication: November 30, 2021

\section{Introduction}

The rapid development of e-commerce brought by internet technology and mobile internet technology has promoted the fast growth of logistics and triggered a significant increase in the demand for logistics talents. As the core professional basic course of logistics engineering and logistics management, Logistics is also an important optional course for students majoring in management and economics. It is a comprehensive interdisciplinary subject with a wide range of knowledge points and strong application. Its research object is the law of "things" in economic activities. However, most of the current teachings of Logistics still follow the traditional "teacher-oriented" model, which has its drawbacks: the "homogenization" and "full-filling" teaching model in the training of logistics talents distastes students; the teaching of theoretical knowledge is far from practice. These cannot meet the current increasing demands for logistics talents and the overall improvement of students' abilities. Therefore, it is urgent to re-examine the current teaching concept and teaching model of Logistics as well as explore new methods and models that meet the current needs of logistics talents. This article discusses on how to design its teaching model based on the OBE concept and its implementation in flipped classroom, so as to innovate the teaching content and enhance students' innovative practice as well as application skills.

\section{Problems existing in the current teaching of Logistics}

In recent years, although many colleges and universities have carried out reform and exploration on the talent training mode of Logistics, achieved huge results, and accumulated many experiences ${ }^{[1,2]}$, compared with other majors, as an emerging logistics major, due to the lack of experience, teachers, experimental facilities, and other resources, there are several curriculum reforms that still requires attention, especially the ones with strong intersections, comprehensiveness, and practicality. 


\subsection{Unclear positioning of the teaching goals and overlapping with other courses}

As a professional basic course for logistics management, logistics engineering, and related majors, Logistics requires students to master the knowledge of management, economics, operations research, system engineering, project management, and financial management, resulting in various problems, such broad teaching objectives and unclear positioning. In addition, the teachers' understanding of the nature of the curriculum and the purpose of teaching are vague and non-uniform. This makes students feel that its contents are complex yet superficial, overlapping with other professional courses, thus affecting students' learning enthusiasm.

\subsection{More emphasis on theory than practice in Logistics teaching}

As a professional basic course, Logistics is often offered during the second or third semester. As freshmen who have just passed the high school entrance examination, they often lack perceptual knowledge related to logistics. In the teaching process, teachers pay too much attention to the teaching of theory, the selected examples as well as situations are far from reality, and there is a lack of practical cases based on current industrial application practice. Furthermore, the persuasiveness and rationality of the cases are weak, the content of the textbook lags behind the development of logistics; the theory is old, and the technology is backward, leaving an adverse impact on the improvement of students' knowledge and their ability to solve practical problems. Hence, students often do not meet the talent needs of actual logistics enterprises.

\subsection{Outdated teaching model and unitary teaching method}

At present, the teaching model of Logistics in colleges and universities still adopts the "full-filling" teaching model of "focusing on teachers." Teachers are strictly assessed based on the completion of the teaching plan or syllabus and whether the specified contents have been explained. In the teaching process, individual differences and the current situation of multi-channel acquisition of knowledge among students in the internet era are largely disregarded. This outdated teaching model and unitary teaching method are not conducive to the expansion of students' knowledge, nor to the improvement of their learning enthusiasm.

\subsection{The rigid assessment of Logistics fails to comprehensively measure the learning effect of students}

Nowadays, the teaching of Logistics focuses on whether the teaching tasks are completed according to the syllabus. Most teachers evaluate the students' learning situation based on their daily results (classroom attendance and homework completion) and final examination results. This rigid and single assessment method cannot comprehensively or objectively evaluate the students' learning situation. In addition, it disregards the assessment of students' basic literacy and practical problem-solving skills. It has seriously affected the learning effect, the improvement of teaching quality, and the teaching level.

\section{Construction of the teaching model of Logistics based on the OBE concept}

Based on the problems in the current teaching of Logistics, this article reconstructed a teaching model by using the OBE concept. The OBE concept was first put forward by Spady in $1981^{\text {[3] }}$. It has developed for more than 30 years and has become the mainstream concept of education reform in the United States, Britain, Canada, and other countries. This concept is a result-oriented, student-centered curriculum system in reverse thinking, which is an advanced education concept. In June 2013, China became a member of the Washington Agreement, which marked the beginning of the educational engineering certification with OBE concept as the core concept in China ${ }^{[4]}$. The OBE concept emphasizes four aspects: expected teaching results, realization of teaching results, evaluation of teaching results, and application of teaching results. 
Taking the logistics engineering major of Guangzhou Maritime University as an example, this article reverse-deduces the knowledge, ability, and quality requirements of Logistics, as a professional basic course, to meet the achievement of these results from the expected teaching results of its professional talent cultivation, as shown in Table 1. Hence, teachers would be able to clearly understand the teaching objectives of Logistics. At the same time, it is necessary to systematically sort out the syllabus of the course and clarify the objectives of the content that should be taught as a professional basic course, so as to effectively avoid duplication in the content of each subdivided specialty course.

Table 1. Achievement degree of the Logistics course to the training objectives of logistics engineering

\begin{tabular}{|c|c|c|}
\hline $\begin{array}{l}\text { Graduation } \\
\text { requirements }\end{array}$ & Index breakdown of graduation requirements & Objectives of the course \\
\hline \multirow{3}{*}{$\begin{array}{l}\text { 1. Quality } \\
\text { structure } \\
\text { requirements }\end{array}$} & $\begin{array}{l}\text { 1-1 Ideological and moral quality: have correct world } \\
\text { outlook, outlook on life, and values; have qualities of } \\
\text { dedication, love for post, honesty, trustworthiness, love } \\
\text { for labor, discipline, law-abiding, unity, and cooperation; } \\
\text { have good ideological and moral character, social } \\
\text { morality, and professional ethics. }\end{array}$ & $\begin{array}{l}\text { Complete course assignments and relevant } \\
\text { course case discussions; pay attention to the } \\
\text { introduction of curriculum thought and politics } \\
\text { while using professional logistics knowledge to } \\
\text { solve problems; cultivate students with good } \\
\text { ideological and moral quality. }\end{array}$ \\
\hline & $\begin{array}{l}\text { 1-2 Cultural quality: have a certain knowledge of } \\
\text { humanities, art, and social sciences; have good } \\
\text { interpersonal communication skills and teamwork skills. }\end{array}$ & $\begin{array}{l}\text { Assume the actual cases related to logistics as } \\
\text { the background; carry out case discussion in } \\
\text { groups; cultivate practical skills, teamwork, } \\
\text { and good communication skills. }\end{array}$ \\
\hline & $\begin{array}{l}\text { 1-3 Professional quality: master the basic theories and } \\
\text { basic knowledge of logistics management and engineering } \\
\text { as well as logistics information; have the basic skills of } \\
\text { logistics engineering project design, logistics system } \\
\text { design, logistics business operation, as well as logistics } \\
\text { equipment design and application; have certain logistics } \\
\text { management ability. }\end{array}$ & $\begin{array}{l}\text { On the basis of mastering the basic knowledge } \\
\text { of logistics and the rational management of } \\
\text { specific functions, be able to correctly } \\
\text { understand the status of logistics in the national } \\
\text { economy and the development direction of } \\
\text { modern logistics. }\end{array}$ \\
\hline \multirow[b]{2}{*}{$\begin{array}{l}\text { 2. Ability } \\
\text { structure } \\
\text { requirements }\end{array}$} & $\begin{array}{l}\text { 2-1 Ability to apply knowledge: able to use basic } \\
\text { theoretical knowledge to guide practice and practical } \\
\text { workability. }\end{array}$ & $\begin{array}{l}\text { On the basis of mastering logistics related } \\
\text { professional knowledge and analyzing actual } \\
\text { cases, learn to master the ability to analyze and } \\
\text { plan various logistic activities. }\end{array}$ \\
\hline & $\begin{array}{l}\text { 2-2 Scientific thinking ability: have certain creative } \\
\text { thinking ability, preliminary scientific research ability, as } \\
\text { well as innovation and entrepreneurship ability by using } \\
\text { the learned knowledge. }\end{array}$ & $\begin{array}{l}\text { Since the development of logistics as a new } \\
\text { industry, every progress is flashing innovative } \\
\text { thinking. Through the investigation of logistics } \\
\text { enterprises after classes, students can learn } \\
\text { about logistics entrepreneurship, so as to } \\
\text { develop innovative consciousness and certain } \\
\text { entrepreneurial skills. }\end{array}$ \\
\hline $\begin{array}{l}\text { 3. Knowledge } \\
\text { structure } \\
\text { requirements }\end{array}$ & $\begin{array}{l}\text { 3-1 Professional knowledge: supply chain management, } \\
\text { logistics system engineering, logistics information } \\
\text { technology, warehouse management, loading and } \\
\text { unloading technology, container transportation, etc. }\end{array}$ & $\begin{array}{l}\text { As a basic course, allow students to have an } \\
\text { advanced understanding of the concept and } \\
\text { framework of the follow-up course. }\end{array}$ \\
\hline
\end{tabular}


In view of space constraints, this article will take the ability structure requirements in the training objectives of logistics engineering professionals to support the graduation requirements of 2-1 and Chapter IV, Logistics Packaging, as an example to comprehensively interpret the teaching model based on the OBE concept, as shown in Figure 1. The reconstructed teaching model has changed the traditional teaching model of "focusing on teachers." Through the teaching reform of flipped classroom, cases related to the current hotspots should be put forward to stimulate students' interest in learning and guide students to learn knowledge principles along with problems, so as to promote "student-oriented" active learning, independent thinking, and innovative thinking, improve the efficiency of classroom teaching, multiply students' after-school learning time, and refine their skills to learn with problems. All of these can also cultivate students' application skills and creativity. The evaluation and application of teaching results are determined through the investigation of actual problems encountered by students, group discussions, and the scoring by instructors. This does not only improve team cooperation, but also help students to learn from each other as well as completely internalize and absorb knowledge better. Evaluation used to be determined by the teacher alone; however, it has changed to both student and teacher evaluations. In this way, students have the right to evaluate and to be "masters" in exercising self-learning and self-evaluation. Teachers have assumed the roles of guides and helpers in students' learning rather than controllers and leaders, thus handing over the learning rights to students.

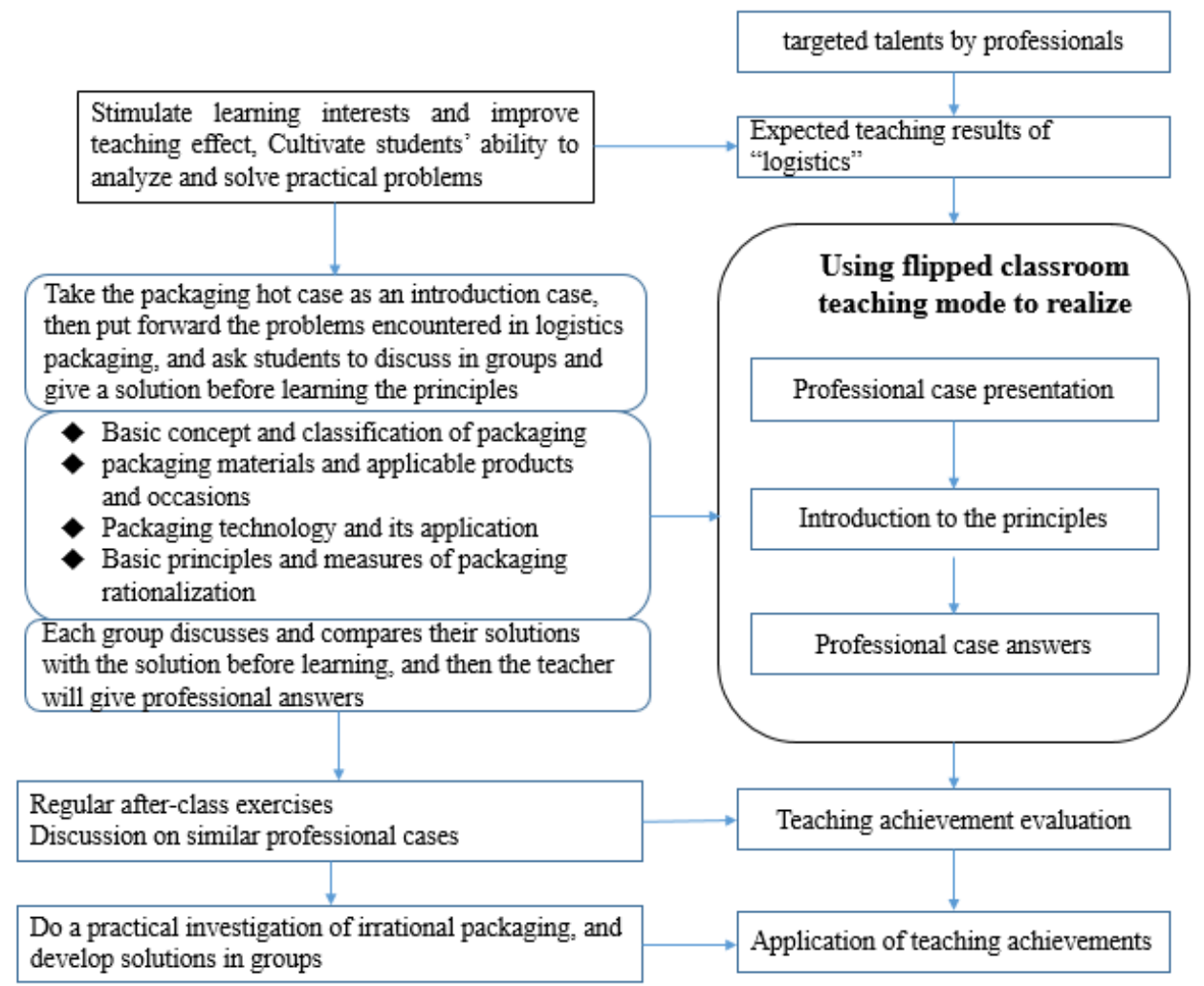

Figure 1. Construction of the teaching model based on OBE with Logistics Packaging as an example

\section{Realization of teaching results by implementing flipped classroom}

After teachers and students have made clear the teaching achievements of the course, a very important link is the realization of teaching achievements. This paper uses flipped classrooms to achieve the given teaching results. The flipped classroom was first formally proposed by American scholars in $2000{ }^{[5]}$. It is a "learning-centered" teaching method which moves away from the framework and constraints of a classroom. 
By readjusting the time inside and outside classrooms, the decision-making power of learning is handed over to the students, so as to ensure that the classroom is truly efficient and conducive to the interaction between teachers as well as students and is assumed as a learning place to deepen and internalize knowledge structure. In flipped classroom, students have strong control over autonomous learning. Teachers need to consider how to help students assimilate autonomous learning and encourage students to cooperate in learning.

In the teaching design of flipped classroom in Figure 1, the teaching design process of flipped classroom based on the OBE concept, taking Chapter IV, Logistics Packaging, as an example, is shown in Figure 2. Each chapter consists of three interconnected links: classroom problem presentation and discussion, self-arranged time after classes to learn theoretical knowledge, and classroom discussion (as shown in Figure 2), which is different from the previous "in-class discussion" course. It is more in line with the law of students' learning. The teaching mode has changed from the original "theory teaching + case analysis" to "enterprise-guided case formulation + video teaching + case analysis." The key points of the implementation are as follows:

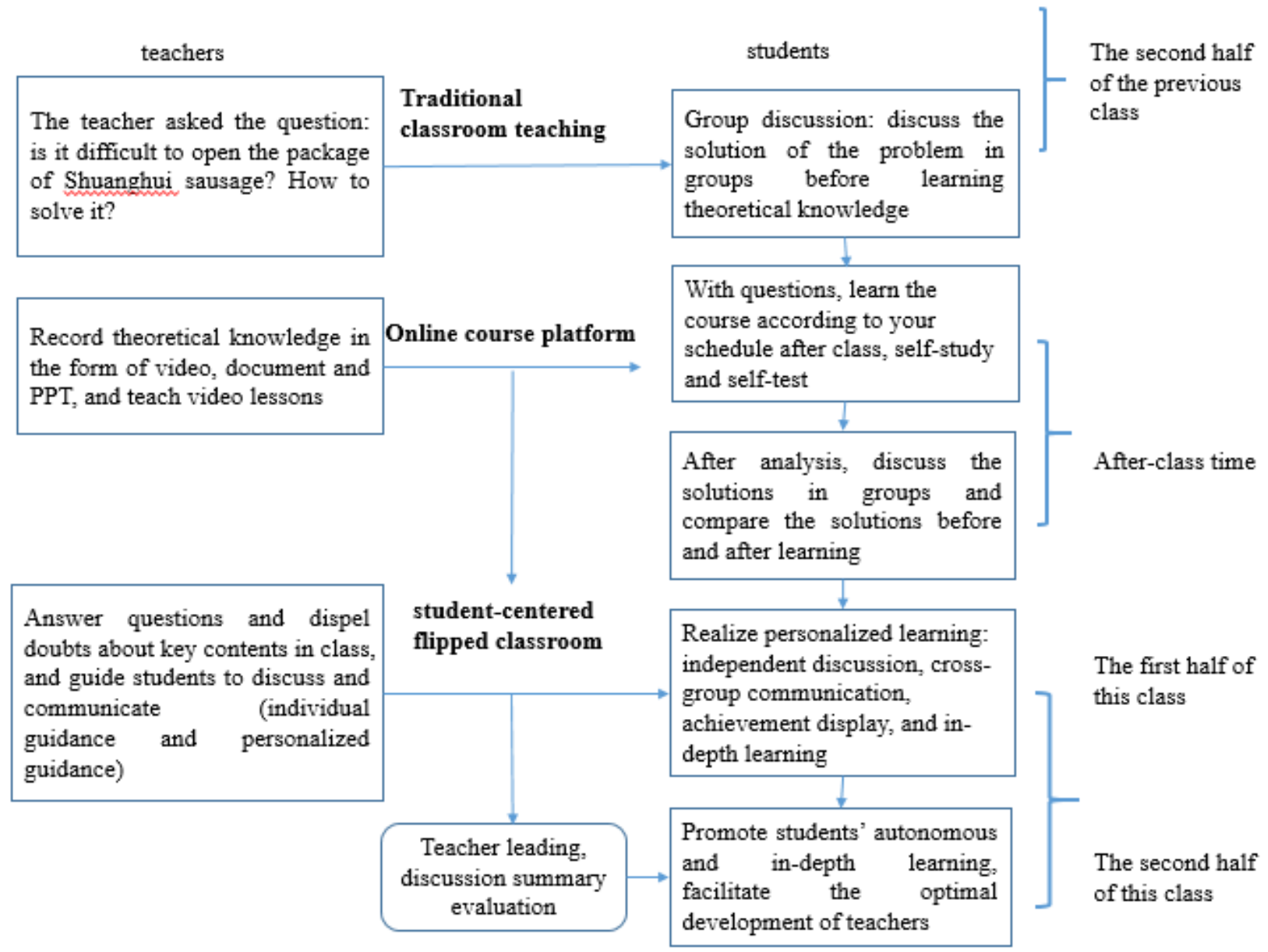

Figure 2. Teaching design process based on the OBE concept

\subsection{Formulation of teaching cases through school-enterprise cooperation}

Building a "professional curriculum case group" between schools and enterprises to analyze and solve practical problems in enterprises forms a bridge for school-enterprise cooperative teaching. This would effectively realize school-enterprise cooperative teaching by using the resources of the society, especially the alumni. Students can submit their practical solutions or results to the enterprises for evaluation or use. 
In this way, students can be exposed to the practical problems in the industry. The theoretical knowledge that they have learned can be combined with practice to cultivate their practical application skills and creativity.

\subsection{Digitization of theoretical courses}

The team members of the course should work together to complete the digitalization of the course. Through the massive open online course (MOOC) platform, students can independently use their spare time to learn and complete online tests after classes. This link is conducive to the transformation of students from passive learning to active learning although there exist individual differences among students in terms of learning. For students who learn fast, they would consume less time to complete their learning, whereas for those who learn in a slower manner, they have the opportunity to repeatedly watch the online course videos to test themselves until they have effectively master the relevant knowledge points. On the one hand, the platform can liberate teachers from repetitive work and give full play to individual differences. Teachers with strong teaching abilities can complete and optimize digital theory courses, while those with strong communication and control ability may have more time to develop professional cases with enterprises and teach students during lessons by answering questions.

\subsection{Implementation of flipped classroom}

The first half of each lesson is completely handed over to the students, in which the students would make decisions. Often, the means of "discussion in separate classes" is applied. It is also the most important link to discuss and internalize the learning content of the previous lesson. Teachers need to design and guide the classroom discussion in advance. Students would conduct an internal inspection first within their groups, test each other's mastery of theoretical knowledge, and share the difficulties encountered in the process of theoretical learning. They would then share their learning achievements by groups. In this manner, each group member is given the opportunity to fully express himself or herself through the activity. In addition to that, cross-group learning can also be realized. This kind of positive and active classroom environment encourages students in a way that they would be more confident to express their ideas. Through this kind of classroom activity, students would be calm and more confident in expressing and displaying themselves in various occasions that they may encounter in the future as well as effectively improve and exercise the ability of teamwork and autonomous learning. This would eventually lead to a transition in students' learning from a shallow learning to deep learning.

\section{Conclusion}

In this article, the flipped classroom model based on the OBE concept in the course is a reverse design of the teaching process of the course based on the goal of professional talent training. After a small-scale trial implementation, it can be appreciated that students have more enthusiasm in learning and creativity in the learning process as they are respected and given stronger leadership in flipped classrooms. At the same time, taking into account the characteristics and differences of college students in the 21 st century, their learning is more efficient, and teachers act as guides for students rather than controllers to effectively improve students' learning enthusiasm and creativity as well as to enable students to gain professional knowledge and skills to apply the knowledge that meets the graduation requirements, along with stronger teamwork, communication, and innovation skills. 


\section{Funding}

This study was supported by the Guangzhou Education Policy Research Project (ZCYJ20109), 2020 Industry University Cooperation Collaborative Education Project (A Letter from the Division of Higher Education [2021] No. 3, 202002325060, 202002325052, 202002325050), 2021 Teaching Construction Project of Guangzhou Maritime University, and 2019 Guangzhou Educational Science Planning Course (201912027).

\section{Disclosure statement}

The author declares that there is no conflict of interest.

\section{References}

[1] Liu J, Chen B, 2017, Discussion on Diversified and Differentiated Assessment of University Courses. Journal of Inner Mongolia Normal University (Educational Science Edition), 30(3): 13-16.

[2] Zong F, Li Z, Jia H, et al., 2014, Optimization of Undergraduate Curriculum Assessment Model Based on Survey. China University Teaching, (9): 76-78.

[3] Xu F, Cheng S, 2020, Teaching Reform of Calculus Based on the OBE Education Concept. Journal of Higher Education, (18): 126-129.

[4] Han J, Zhang M, 2020, Research on Teaching Mode of Innovation and Entrepreneurship Project Based on the OBE Concept. Experimental Technology and Management, (2): 209-212.

[5] Wang X, 2019, Reform and Practice of Flipped Classroom of Bulk Commodity Logistics based on the OBE Education Concept. Modern Business and Trade Industry, (26): 192-195. 